\title{
An Osteopathic Modular Approach to Asthma: A Narrative Review
}

Jason Schend, DO; Marija Rowane, OMS III; Neha Sanan, DO;

Sir Robert Hostoffer, Jr., DO, LhD, MSMEd

From the University Hospitals (UH) Pediatric \& Adult Allergy/ Immunology Fellowship Program, Department of

Pulmonary Critical Care at University Hospitals Cleveland Medical Center in Cleveland, Ohio (Drs. Schend, Sanan, and Hostoffer); and the Ohio University Heritage College of Osteopathic Medicine in Athens, Ohio (Student Dr Rowane).

Disclaimer: Dr Hostoffer is the American Osteopathic Association Board of Trustees representative on the JAOA's Editorial Board.

Financial Disclosures: None reported.

Support: None reported.

Address correspondence to Marija Rowane, OMS III,

Allergy/ Immunology

Associates, Inc., 5915 Landerbrook Drive, Suite 110, Mayfield Heights, Ohio 44124-4034. Email: mr388917@ohio.edu Submitted August 7, 2019; revision received December 16, 2019; accepted February 10, 2020
Asthma is among of the first ailments documented in the existing academic literature as being successfully managed with osteopathic manipulative treatment (OMT) techniques. Time-efficient and well-tolerated OMT techniques have been gradually added to the literature to manage this increasingly prevalent disease. In this narrative review, the authors discuss previouslypublished literature describing the history, diagnosis, and management of asthma related to osteopathic principles and practices and OMT application. They also present current and newly-approved medical managements, including biologics and inhaled corticosteroids. This article also includes supplemental videos showcasing OMT techniques for asthma management, which were developed by the authors based on recommendations indicated in the literature.

J Am Osteopath Assoc. 2020;120(11):774-782. Published online September 22, 2020. doi:10.7556/jaoa.2020.121

Keywords: asthma, bronchial asthma, bronchitis, chronic lung disease, COPD, OMT

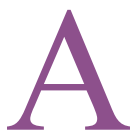
sthma and its management have been recognized for millennia and recorded in both medical and nonmedical literature. Since the oldest historical reference of the "noisy" and "troubled" breathing of patients with asthma was described by China's Emporer Huang Ti (2698-2598 BC) ${ }^{1}$ and Hippocrates' description of $\alpha \sigma \theta \mu \alpha$ ("to exhale with an open mouth, to pant"), ${ }^{2}$ our understanding of asthma has evolved to the molecular mechanisms and advanced management of today, far beyond the initial inhalation apparatuses described in Ebers Papyrus. ${ }^{3}$ Contemporary practice includes pharmacologic therapies like inhaled corticosteroids (ICS) and biological agents, specific to the various asthma phenotypes: early-onset allergic, late-onset eosinophilic, exercise-induced, obesity-related, and neutrophilic asthma (Table 1). ${ }^{4-5}$ The Global Initiative for Asthma (GINA) has recommended personalized management to control asthma symptoms and minimize future exacerbation risk, beginning with low-dose ICSs and short-acting beta-agonists (SABAs) as needed (Table 2). ${ }^{6}$ Biological therapy has been a topic of increasingly-frequent research and is in demand for decreasing severe airway inflammation during asthma exacerbations (Table 3). ${ }^{6-18}$

Osteopathic treatment for asthma began in the 1870s and has targeted 3 areas: addressing somatic dysfunction of thoracic spine and ribs, improving diaphragmatic function, and balancing sympathetic and parasympathetic dysregulation. ${ }^{19-24}$ Patients with asthma have multiple systems involved in the inherent pathophysiology of their disease: biomechanical, metabolic, respiratory/circulatory, musculoskeletal, and behavioral. Early 


\section{Table 1.}

\section{Asthma Phenotypes and Clinical Characteristics}

\begin{tabular}{llll} 
Phenotypes & $\begin{array}{l}\text { Natural history and clinical } \\
\text { characteristics }\end{array}$ & $\begin{array}{l}\text { Pathology and } \\
\text { biomarkers }\end{array}$ & Therapies \\
\hline Early-onset allergic & $\begin{array}{l}\text { Early onset; mild-to-severe symptoms; } \\
\text { frequently associated with atopy }\end{array}$ & $\begin{array}{l}\text { Elevated Total/Specific } \\
\text { lgE; Th2 cytokines; } \\
\text { thickened SBM }\end{array}$ & $\begin{array}{l}\text { Monoclonal antibody to IgE, } \\
\text { Th2-targeted CS }\end{array}$ \\
\hline $\begin{array}{l}\text { Late-onset } \\
\text { eosinophilic }\end{array}$ & $\begin{array}{l}\text { Adult onset; often severe symptoms; } \\
\text { increased eosinophils in sputum; less } \\
\text { allergic; includes AERD }\end{array}$ & $\begin{array}{l}\text { CS-refractory } \\
\text { eosinophilia; IL-5 }\end{array}$ & $\begin{array}{l}\text { Monoclonal antibodies to IL-5/ } \\
\text { IL-5R, IL-4R and cysteinyl } \\
\text { leukotriene modifiers }\end{array}$ \\
\hline $\begin{array}{lll}\text { Exercise-induced } \\
\text { Intermittent with exercise; mild } \\
\text { symptoms }\end{array}$ & $\begin{array}{l}\text { Mast-cell activation; Th2 } \\
\text { cytokines; cysteinyl }\end{array}$ & $\begin{array}{l}\text { Cysteinyl leukotriene modifiers, } \\
\text { beta agonists, antibody to IL-9 }\end{array}$ \\
\hline Obesity-related & $\begin{array}{l}\text { Adult onset; females; increased OCS } \\
\text { leuke; nonatopic }\end{array}$ & $\begin{array}{l}\text { Lack of Th2 biomarkers; } \\
\text { oxidative stress }\end{array}$ & $\begin{array}{l}\text { Weight loss, antioxidants, } \\
\text { hormonal therapy }\end{array}$ \\
\hline Neutrophilic & $\begin{array}{l}\text { Low FEV } \text {; significant air trapping; } \\
\text { frequent OCS use }\end{array}$ & $\begin{array}{l}\text { Sputum neutrophilia; } \\
\text { Th17 pathways; IL-8 }\end{array}$ & Macrolide antibiotics
\end{tabular}

Abbreviations: AERD, aspirin-exacerbated respiratory disease; CS, corticosteroids; IL, interleukin; IgE, immunoglobulin E; FEV 1 , forced expiratory volume in 1 second; OCS, oral corticosteroids; SBM, subepithelial basement membrane.

Adapted from Wenzel $2012^{4}$ and Tabatabaian 2019. ${ }^{5}$

$20^{\text {th }}$-century discussions by Moore ${ }^{21}$ and Oium, ${ }^{22}$ a 1993 editorial by Allen and D'Alonzo, ${ }^{23}$ a 1996 clinical practice guide by Paul and Buser, ${ }^{24} 1999$ literature reviews by W.A. and M.P. Rowane ${ }^{19}$ and Jackson and Steele, ${ }^{20}$ a 2004 review by Salamon, ${ }^{25}$ and a 2013 systemic review of randomized control trials (RCTs) by Piosadski et $\mathrm{al}^{26}$ are among the limited osteopathic literature describing the pathogenesis and osteopathic treatment of asthma. ${ }^{27-30}$ Other studies have provided evidence of the benefit of osteopathic manipulative treatment (OMT) through pilot studies ${ }^{31-32}$ and a pediatric randomized clinical trials (RCTs), ${ }^{26,28,30}$ as well as evidence regarding other nonpharmacologic therapies, such as acupuncture and chiropractic manipulation, ${ }^{30,33-35}$ in asthma management. No animal models, nor any expansive clinical studies or RCTs, exist in the literature to further support recommendations for these adjunctive therapies. Here, we present an updated review of asthma, its pharmacologic treatments, and the most common and effective OMT techniques for managing this chronic lung disease.

\section{Literature Search Methods}

We performed a targeted search through osteopathic medical libraries and various databases, including the Museum of Osteopathic Medicine and International Center for Osteopathic History (ICOH) at A.T. Still University, PubMed, Osteopathic Medical Digital Repository (OSTMED. DR), Lippincott Williams and Wilkins Health Library/Osteopathic Health Library, Ovid, Cochrane Library, and Google Scholar. Search terms included osteopathic manipulative treatment, OMT, osteopathic manipulative medicine, OMM, osteopathic principles and practices, OPP, asthma, bronchial asthma, chronic lung disease, COPD, and bronchitis. Our searches were conducted without limitation on publication dates. A total of 32 manuscripts published between 1899 and 2019 contained information about osteopathic physicians' approaches to asthma. ${ }^{24-30,33-63}$ Several contained information about current and newly approved medical treatments, including biologics and inhalers (Table 2, Table 3) ${ }^{60-62} \mathrm{We}$ reviewed each publication for its methodology, size, 
Table 2A.

Personalized Asthma Step Management for Adults and Adolescents ( $\geq 12$ years old) to Control Symptoms and Minimize Future Exacerbation Risk: Preferred Controllers and Relievers*

\begin{tabular}{|c|c|c|c|c|}
\hline Step & Preferred controller & Other controller & Preferred reliever & $\begin{array}{l}\text { Other } \\
\text { reliever } \\
\text { options }\end{array}$ \\
\hline 2 & $\begin{array}{l}\text { Daily low-dose ICS, or as-needed low } \\
\text { dose ICS-formoterol }\end{array}$ & $\begin{array}{l}\text { LTRA, low-dose ICS } \\
\text { with SABA }\end{array}$ & $\ldots$ & $\ldots$ \\
\hline 3 & Low-dose ICS-LABA & $\begin{array}{l}\text { Medium-dose ICS, } \\
\text { or low-dose ICS } \\
+ \text { LTRA }^{d}\end{array}$ & $\begin{array}{l}\text { As-needed low dose } \\
\text { ICS-formoterol for patient } \\
\text { prescribed maintenance and } \\
\text { reliever therapyc }\end{array}$ & $\ldots$ \\
\hline
\end{tabular}

a off-label, data only with budesonide-formoterol (bud-form); ${ }^{b}$ off-label, separate or combination ICS and SABA inhalers; ${ }^{c}$ low-dose ICS-form is the reliever for patients prescribed bud-form or beclomethasone-diproprionate form maintenance and reliever therapy; ${ }^{\mathrm{d}}$ consider adding house dust mites sublingual immunotherapy for sensitized patients with allergic rhinitis and FEV $1>70 \%$ predicted; ${ }^{\mathrm{e}}$ consider side effects DPI.

${ }^{*}$ Refer to Table 2B for specific inhaled corticosteroid potencies and dosages.

Abbreviations: DPI, dry powder inhaler; ICS, inhaled corticosteroid; IgE, immunoglobulin E; IL, interleukin; LTRA, leukotriene-receptor antagonist; LABA, long-acting $\beta 2$-agonist; OCS, oral corticosteroids; SABA, Short-acting 32 -agonist.

Adapted from Tabatabaian $2019^{5}$ and Global Initiative for Asthma (GINA) $2019 .^{6}$

Table 2B.

Differentiation of Inhaled Corticosteriods According to Potency*

\begin{tabular}{|c|c|c|c|c|c|}
\hline Low-dose & mcg & Medium-dose & mcg & High-dose & mcg \\
\hline $\begin{array}{l}\text { Beclomethasone } \\
\text { dipropionate (HFA) }\end{array}$ & $100-200$ & $\begin{array}{l}\text { Beclomethasone } \\
\text { dipropionate (HFA) }\end{array}$ & $>200-400$ & $\begin{array}{l}\text { Beclomethasone } \\
\text { dipropionate (HFA) }\end{array}$ & $>400$ \\
\hline Ciclesonide (HFA) & $80-160$ & Ciclesonide (HFA) & $>160-320$ & Ciclesonide (HFA) & $>320$ \\
\hline Fluticasone furoate (DPI) & 100 & Fluticasone propionate & $>250-500$ & Fluticasone furoate (DPI) & 200 \\
\hline $\begin{array}{l}\text { Fluticasone propionate } \\
\text { (DPI or HFA) }\end{array}$ & $100-250$ & $\begin{array}{l}\text { (DPI or HFA) } \\
\text { Mometasone furoate }\end{array}$ & $>220-440$ & $\begin{array}{l}\text { Fluticasone propionate } \\
\text { (DPI or HFA) }\end{array}$ & $>500$ \\
\hline Mometasone furoate & $110-220$ & Triamcinolone acetonide & $>1000-2000$ & Mometasone furoate & $>440$ \\
\hline Triamcinolone acetonide & $400-1000$ & & & Triamcinolone acetonide & $>2000$ \\
\hline
\end{tabular}

Abbreviations: DPI, dry powder inhaler; HFA, hydrofluoroalkane propellant.

${ }^{*}$ Refer to Table 2A for an outline of preferred controllers and relievers.

Adapted from Tabatabaian $2019^{5}$ and Global Initiative for Asthma (GINA) $2019 .^{6}$ 
Table 3.

Biologics Targeting T2-high Asthma

\begin{tabular}{|c|c|c|c|c|}
\hline Therapies & Mechanism of action & Potential biomarkers & Effect & \\
\hline Mepolizumab & IL-5 antagonist & $\begin{array}{l}\text { Peripheral eosinophil count } \\
>150 \text { cells } / \mu \mathrm{L} \text { or } 300 \text { cells } / \mu \mathrm{L}\end{array}$ & $\begin{array}{l}\text { Decrease } \\
\text { asthma } \\
\text { exacerbations }\end{array}$ & $\begin{array}{l}\text { Improvement in } \\
\text { pre-post } \\
\text { bronchodilator } \mathrm{FEV}_{1}\end{array}$ \\
\hline Reslizumab & IL-5 antagonist & $\begin{array}{l}\text { Peripheral eosinophil count } \\
>400 \text { cells } / \mu \mathrm{L}\end{array}$ & $\begin{array}{l}\text { Decrease } \\
\text { asthma } \\
\text { exacerbations }\end{array}$ & $\begin{array}{l}\text { Improvement in } \\
\text { FEV }_{1}\end{array}$ \\
\hline Benralizumab & $\begin{array}{l}\text { IL- } 5 \text { receptor; } \alpha \text {-antagonists } \\
\text { targeting both eosinophils and } \\
\text { basophils }\end{array}$ & $\begin{array}{l}\text { Elevated peripheral blood } \\
\text { eosinophil count }\end{array}$ & $\begin{array}{l}\text { Decrease } \\
\text { asthma } \\
\text { exacerbations }\end{array}$ & $\ldots$ \\
\hline
\end{tabular}

Abbreviations: FceRI, high affinity receptor for the fragmented crystallizable region of immunoglobulin $\mathrm{E}$; FeNO, fractional exhaled nitric oxide $F E V_{1}$, forced expiratory volume in 1 second; IgE, immunoglobulin $\mathrm{E}$; IL, interleukin.

Adapted from information provided in Tabatabaian, ${ }^{5}$ Hanania et al, ${ }^{7}$ Humbert et al, ${ }^{8}$ Pavord et al, ${ }^{9}$ Haldar et al, ${ }^{10}$ Flood-Page et al, ${ }^{11}$ Ortega et al, ${ }^{12}$ Corren et al, ${ }^{13}$ Laviolette et al, ${ }^{14}$ Nowak et al,,${ }^{15}$ Wenzel et al, ${ }^{16}$ Castro et al, ${ }^{17}$ Busse et al ${ }^{18}$

scope, and relevance to the management of asthma for the practicing clinician. The results of these studies are discussed below by topic.

\section{Biomechanical Mechanism of Treatment}

Somatic dysfunction leading to bronchospasm, via aberrant viscerosomatic sympathetic tone, has been associated with bilateral and ipsilateral T2-T7 thoracic segments. ${ }^{47-49}$ Allen and Alonzo $^{23}$ documented common dysfunctions recognized in acute asthma, including "lesions" in the "second to fourth thoracic vertebra," elevation of the "fourth rib of the right," and a "lesion of the third cervical vertebrae with rotation to the left." Asthma symptoms, including bronchospasm and increased mucus production, have also been attributed to elevated parasympathetic tone. ${ }^{52}$ Rib and spinal segmental dysfunction can lead to a reduction in optimal ventilation. ${ }^{34}$ Musculature that supports these bony structures can become hypertonic or even fatigued to the point of failure. Direct and indirect OMT techni- ques can help to maximize chest wall excursion in both inhalation and exhalation. ${ }^{24}$

Common techniques to manage acute asthma exacerbations include various combinations of rib raising, myofascial release (MFR), balanced ligamentous tension (BLT), high velocity-low amplitude (HVLA), and thoracic pump. ${ }^{33,52}$ Fatigued hypertonic accessory muscle groups include the cervical strap and intercostal muscles. BLT and the other OMT techniques may be performed several times, as needed, when the patient remains dyspneic and struggles to breathe. ${ }^{51}$ Guiney et $\mathrm{al}^{28}$ conducted an RCT using rib raising, muscle energy, and myofascial release in an OMT sequence that resulted in notable improvements $(25 \%-70 \%)$ in patients' peak expiratory flow (PEF) rates in 90 female pediatric patients' peak expiratory flow rates and, ultimately, chest wall motion. ${ }^{34}$

Direct and indirect inhibition of parasympathetic tone has been described by osteopathic physicians for over a century as an asthma management. ${ }^{26,34,53,54}$ Addressing 
the occipitoatlantal $(\mathrm{OA})$ region via decompression, the upper cervical spine via MFR and strain-counterstrain, and the vagus nerve via direct inhibition can lessen bronchoconstriction present in the asthmatic airway (Supplemental Video 1 and Video 2). ${ }^{26}$ Decreased mucus production may require more time to resolve and may therefore necessitate repeated treatments.

\section{Respiratory/Circulatory Mechanism of Treatment}

The pump action of the abdominal diaphragm is not only vital for gas exchange, but it also has an integral role in lymphatic drainage and the low-pressure vascular circulatory loop in the lungs. ${ }^{63}$ Although OMT did not change vital capacity or residual volume in preliminary studies reported by Allen and D'Alonzo, ${ }^{23}$ improved work capacity, arterial carbon dioxide tension, oxygen saturation, total lung capacity, and residual volume, as well as reduced dyspnea and fewer upper respiratory tract infections, have been demonstrated from OMT elsewhere. Creasy et $\mathrm{al}^{51}$ demonstrated that diaphragmatic movement is a crucial element in maintaining lymph and vascular flow in the thoracic and abdominal spaces. In the supplemental videos accompanying this manuscript, we demonstrate thoracic pump and diaphragm doming techniques for addressing these mechanisms.

OMT techniques are helpful as an adjunct therapy for asthma exacerbations to improve mechanical functioning of the thoracic cage and balance the autonomic nervous system. ${ }^{48}$ Guiney et al, ${ }^{28}$ Bockenhauer et al, ${ }^{27}$ and Allen and Kelso ${ }^{42}$ demonstrated direct effect of OMT on mechanical restrictions and respiratory excursion in patients with respiratory disease. Although Guiney et $\mathrm{al}^{28}$ improved peak expiratory flow rates after OMT application (7-9 L/min, 22\% increase), forced expiratory volume in 1 second $\left(\mathrm{FEV}_{1}\right)$, and flowcontrolled ventilation (FVC) would provide a more accurate assessment of respiratory function. Regardless, OMT intervention has been beneficial for asthma management by decreasing anxiety resulting from respiratory distress and improving chest wall function. ${ }^{48}$

\section{Metabolic Mechanism of Management}

Strides have been made in the last several years in asthma management. Inhaled corticosteroids, longacting beta agonists, anticholinergics (including longacting formulations now approved for asthma), arachidonic acid pathway inhibitors, and monoclonal antibodies - collectively referred to as "biologics" - are the latest evolutions in asthma treatment. ${ }^{60-62}$ Targeted therapies using biologics to alter pathologic pathways are now approved for patients with moderate-to-severe, persistent asthma. ${ }^{60-62}$ (Table 3)

Classifying asthma phenotypes is a burgeoning approach to determine which of the 5 biologics on the market to prescribe for asthma management. ${ }^{62}$ Omalizumab was the first FDA-approved monoclonal antibody for asthma treatment. ${ }^{7-8,62}$ Its mechanism of action is binding unbound immunoglobulin $\mathrm{E}(\operatorname{IgE})$ in tissues and circulation. ${ }^{7-8,62} \mathrm{IgE}$ is ligated to omalizumab, blocked from receptor binding, and prevented from receptor cross-linking, subsequently leading to granulocyte degranulation. ${ }^{7-8,62}$

Mepolizumab is an interleukin (IL)-5 antagonist that has potent antieosinophilic and inflammatory action in the lungs. ${ }^{9-12,62}$ Elevated eosinophil levels are common in patients with moderate-to-severe persistent asthma. ${ }^{8-9,62}$ Reslizumab is another IL-5 antagonist, available only as an infusion and dosed by weight; thus, it is useful for patients with higher BMIs. ${ }^{13,62}$ Benralizumab is an IL-5 receptor antagonist that not only blocks the effects of eosinophils but also reduces their number and longevity. ${ }^{14-15,62}$

Dupilumab is an IL-4 receptor $\alpha$-subunit antagonist that works to mitigate the effects of potent inflammatory ILs, including IL-4 and IL-13. ${ }^{16-17,62}$ The advent of biologics is viewed as a major "game-changer" for chronic diseases across many fields.

\section{Neurologic Mechanism of Treatment}

In the early $20^{\text {th }}$ century, Coffman argued against the popular belief that asthma was not a primary neurosis manifested solely by psychological perturbations. ${ }^{52} \mathrm{He}$ stated that the neurologic component of asthma was an 
integral part of the disease pathophysiology, but was not "all in the head" of the patient. ${ }^{52}$ He reasoned that any neurosis was secondary "to a disturbance of the muscles of the bronchi, producing dyspnae," leading to anxiety associated with shortness of breath. ${ }^{52}$ Henley et al emphasized OMT to address the adversarial roles of the sympathetic chain (T1-T6) and parasympathetics (vagus nerve) that innervate bronchial smooth muscles. ${ }^{53}$ Management that helps normalize sympathetic tone by addressing somatic dysfunctions can be used. $^{19,49}$ Rib raising and thoracic HVLA are 2 common OMT techniques that may occupy a few minutes at the end of the physical examination (Supplemental Videos 1 and 2). Gentle craniosacral techniques are additionally proposed to address common conditions, as well as asthma symptoms. ${ }^{42}$

Osteopathic interventions that improve thoracic mobility favorably affect the regulatory mechanisms of the autonomic nervous system. ${ }^{27}$ Parasympathetic innervation sets the tone in the bronchial smooth muscles. Increased parasympathetic expression can lead to bronchoconstriction. Parasympathetic signaling also increases secretory function in many tissues that may instigate mucus hypersecretion in the lungs. Pathologic deviations in parasympathetic tone have been associated with reduced response to adrenergic agonists and exaggerated responses to cholinergic medications that lead to increased parasympathetic tone. ${ }^{64}$ Oium $^{22}$ substantiated the application of OA decompression and direct vagal inhibition address this parasympathetic tone. These techniques aim to inhibit parasympathetic tone, thereby allowing bronchodilation and decreasing mucus production thereafter. In 2008, through position changes with a tilt table, Henley et $\mathrm{al}^{53}$ demonstrated that parasympathetic responses overcome sympathetic tone.

\section{Behavioral Mechanism of Treatment}

Failure to evaluate and manage existing psychodynamic issues may exacerbate the symptom complex of asthma. ${ }^{65-68}$ Patients with asthma are at higher risk for mood disorders and anxiety. ${ }^{65-68}$ This risk is even higher in pediatric and adolescent patients, who may feel ostracized because of their physical limitations and frequent absenteeism. ${ }^{68}$ Depression and anxiety affect medication compliance and thus worsen disease. Choi et $\mathrm{al}^{65}$ provided evidence of bi-directionality between the presence or development of asthma in adults and depression and anxiety. The core osteopathic tenets, of course, emphasize this equilibrium: "(1) The human being is a dynamic unit of function, (2) the body possesses self-regulatory mechanisms that are self-healing in nature, (3) structure and function are interrelated at all levels, and (4) rational treatment is based on these principles." 69 The ubiquitous Asthma Control Test and other asthma symptom questionnaires have been suggested to detect emotional issues through lower scores. $^{28}$ A preliminary study by D'Ippolito et $\mathrm{al}^{31}$ documented significant improvement in depression and anxiety symptoms among 11 patients with highfrequency migraine and comorbid mood disorders after 4 OMT sessions $(P<.05)$. Wiegand et $\mathrm{al}^{32}$ conducted a randomized, controlled pilot study that indicated statistically significant decrease in self-perceived fatigue among 1st-year osteopathic medical students receiving direct OMT. Blumer and Blumer ${ }^{70}$ proposed the following OMT sequence for anxiety disorder management: cervical soft tissue/long axis kneeding, cervical high velocity/low amplitude, sacral decompression, suboccipital/occipitoatlantal decompression, doming of the respiratory diaphragm, and compression of the fourth ventricle. Relaxation techniques, diaphragmatic breathing, biofeedback, psychological counseling, and patient and family education may also decrease asthma morbidity from depression and anxiety. ${ }^{71}$

\section{Conclusion}

Asthma is among the first ailments successfully managed with OMT in the literature. However, extensive, controlled studies and RCTs applying OMT as an adjunctive therapy asthma management have not been pursued. OMT recommendations have been gradually added to the literature to manage this increasingly 
prevalent disease, but further larger-scale studies are warranted to verify their efficacy. The whole-person philosophy, including psychological and behavioral management for asthma, is not a novel concept in osteopathic medicine; the application of these treatment approaches will continue to yield improvements in asthma management.

\section{Author Contributions}

All authors provided substantial contributions to conception and design, acquisition of data, or analysis and interpretation of data; all authors drafted the article or revised it critically for important intellectual content; all authors gave final approval of the version of the article to be published; and all authors agree to be accountable for all aspects of the work in ensuring that questions related to the accuracy or integrity of any part of the work are appropriately investigated and resolved.

\section{References}

1. Ti H. Nei Ching Su Wen, The Yellow Emperor's Classic of Internal Medicine. Veith I, trans-ed. Baltimore, MD: Williams \& Wilkins; 1949.

2. Hippocrates. Corpus Hippocraticum. Potter P. Harvard University Press; 1938;5(51):285

3. Ebbell B. The Papyrus Ebers: The Greatest Egyptian Medical Document. Levin and Munksgaard; 1937.

4. Wenzel SE. Asthma phenotypes: the evolution from clinical to molecular approaches. Nat Med. 2012;18(5):716-725. doi:10.1038/nm.2678

5. Tabatabaian F. Asthma phenotypes and biomarkers. In Massoud M, ed. Allergy and Asthma: The Basics to Best Practices. Springer Nature Switzerland AG; 2019: 275-288.

6. Global Initiative for Asthma (GINA). Global Strategy for Asthma Management and Prevention, 2019. www.ginasthma.org. Accessed September 11, 2020.

7. Hanania NA, Wenzel S, Rosen K, et al. Exploring the effects of omalizumab in allergic asthma: an analysis of biomarkers in the EXTRA study. Am J Respir Crit Care Med. 2013;187(8):804-811. doi:10.1164/rccm.201208-1414OC

8. Humbert M, Busse W, Hanania NA, et al. Omalizumab in asthma: an update on recent developments. J Allergy Clin Immunol Pract. 2014;2 (5):525-536. doi:10.1016/j.jaip.2014.03.010

9. Pavord ID, Korn S, Howarth P, et al. Mepolizumab for severe eosinophilic asthma (DREAM): a multicentre, double-blind, placebo-controlled trial. Lancet. 2012;380(9842):651-659. doi:PIIS0140-6736(12)60988-X

10. Haldar P, Brightling CE, Hargadon B, et al. Mepolizumab and exacerbations of refractory eosinophilic asthma. NEJM. 2009;360 (10):973-984. doi:10.1056/NEJMoa0808991

11. Flood-Page $\mathrm{P}$, Swenson $\mathrm{C}$, Faiferman I, et al. A study to evaluate safety and efficacy of mepolizumab in patients with moderate persistent asthma. Am J Respir Crit Care Med. 2007;176 (11):1062-1071. doi:10.1164/rccm.200701-085OC
12. Ortega HG, Liu MC, Pavord ID, et al. Mepolizumab treatment in patients with severe eosinophilic asthma. N Engl J Med. 2014;371 (13):1198-1207. doi:10.1056/NEJMoa0808991

13. Corren J, Weinstein S, Janka L, Zangrilli J, Garin M. Phase 3 study of reslizumab in patients with poorly controlled asthma: effects across a broad range of eosinophil counts. Chest. 2016;150(4):799-810. doi:10.1016/j.chest.2016.03.018

14. Laviolette M, Gossage DL, Gauvreau G, et al. Effects of benralizumab on airway eosinophils in asthmatic patients with sputum eosinophilia. J Allergy Clin Immunol. 2013;132(5):1086-1096. doi:10.1016/j. jaci.2013.05.020

15. Nowak RM, Parker JM, Silverman RA, et al. A randomized trial of benralizumab, an antiinterleukin 5 receptor alpha monoclonal antibody, after acute asthma. Am J Emerg Med. 2015;33(1):14-20. doi:10.1016/j. ajem.2014.09.036

16. Wenzel S, Castro M, Corren J, et al. Dupilumab efficacy and safety in adults with uncontrolled persistent asthma despite use of medium-to-high-dose inhaled corticosteroids plus a long-acting beta2 agonist: a randomised double-blind placebo-controlled pivotal phase 2b dose-ranging trial. Lancet. 2016; 388(10039):31-44. doi:10.1016/j. ajem.2014.09.036

17. Castro M, Corren J, Pavord ID, et al. Dupilumab efficacy and safety in moderate-to-severe uncontrolled asthma. NEJM. 2018;378:2486-2496. doi:10.1056/NEJMoa1804092

18. Busse WW, Maspero JF, Rabe KF, et al. Liberty asthma QUEST: phase 3 randomized, double-blind, placebo-controlled, parallel-group study to evaluate dupilumab efficacy/safety in patients with uncontrolled, moderate-to-severe asthma. Adv Ther. 2018;35:737. doi:10.1007/s12325-018-0702-4

19. Rowane WA, Rowane MP. An osteopathic approach to asthma. J Am Osteopath Assoc. 1999;99(5):259-264. doi:10.7556/ jaoa.1999.99.5.259

20. Jackson KM, Steele KM. Osteopathic treatment of asthma: a literature review and a call for research. AAOJ. 1999; 9(4):23-27.

21. Moore FE. Discussion of asthma. J Am Osteopath Assoc. 1907; 7:88-89.

22. Oium FN. Cause and cure of asthma. J Am Osteopath Assoc. 1917: 17(3);150-151

23. Allen TW, D'Alonzo GE. Investigating the role of osteopathic manipulation in the treatment of asthma. J Am Osteopath Assoc. 1993; 93:654-655,659.

24. Paul FA, Buser BR. Osteopathic manipulative treatment applications for the emergency department patient. J Am Osteopath Assoc. 1996; 96(7):403-409

25. Salamon E. Nitric oxide as a possible mechanism for understanding the therapeutic effects of osteopathic manipulative medicine (review). Int J Mol Med. 2004;14(3). doi:10.3892/ijmm.14.3.443

26. Posadzki P, Lee MS, Ernst E. Osteopathic manipulative treatment for pediatric conditions: a systematic review. Pediatrics. 2013; 132:140-152. doi:10.1542/peds.2012-3959

27. Bockenhauer SE, Julliard KN, Lo KS, Huang E, Sheth AM. Quantifiable effects of osteopathic manipulative techniques on patients with chronic asthma. J Am Osteopath Assoc. 2002; 371-375.

28. Guiney PA, Chou R, Vianna A, Lovenheim J. Effects of osteopathic manipulative treatment on pediatric patients with asthma: a randomized controlled trial. J Am Osteopath Assoc. 2005;105:7-12. 
29. Lee-Wong M, Karagic M, Gomez S, et al. Adding osteopathic intervention to albuterol nebulization in ambulatory asthma exacerbations. Internet J Asthma Allergy Immunol. 2008; 7(2):1-5.

30. Balon J, Crowther ER, Crowther DC, et al. A comparison of active and simulated chiropractic manipulation as adjunctive treatment for childhood asthma. NEJM. 1998; 339(15):1013-20. doi:10.1056/ NEJM199810083391501

31. D'Ippolito M, Tramontano M, Buzzi MG. Effects of osteopathic manipulative therapy on pain and mood disorders in patients with high-frequency migraine. J Am Osteopath Assoc. 2017;117 (6):365-369. doi:10.7556/jaoa.2017.074

32. Wiegand S, Bianchi W, Quinn TA. Osteopathic manipulative treatment for self-reported fatigue, stress, and depression in first-year osteopathic medical students. J Am Osteopath Assoc. 2015;115 (2):84-93. doi:10.7556/jaoa.2015.019

33. Balon JW, Mior SA. Chiropractic care in asthma and allergy. Ann Allergy Asthma Immunol. 2004; 93(Suppl 1):S55-S60. doi:10.1016/ s1801-1206(10)61487-1

34. Nielsen NH, Bronfort G, Bendix T, et al. Chronic asthma and chiropractic spinal manipulation: a randomized clinical trial. Clin Exp Allergy. 1995;25(1):80-88. doi:10.1111/j.1365-2222.1995.tb01006.x.

35. Ernst E. Spinal manipulation for asthma: a systematic review of randomised clinical trials. Respir Med. 2009;103:1791-1795.

36. Ziment I, Tashkin DP. Alternative medicine for allergy and asthma. J Allergy Clin Immunol. 2000; 106:603-14. doi:10.1067/ mai.2000.109432

37. Hondras MA, Klaus L, Jones AP. Manual therapy for asthma. (Protocol). Cochrane Database of Syst Rev. 2005; 2(CD001002). doi:10.1002/14651858.CD001002

38. Attlee T. Cranio-sacral therapy and the treatment of common childhood conditions. Health Visitor. 677 (1994): 232-234.

39. Still AT. The Philosophy and Mechanical Principles of Osteopathy. Hudson-Kimberly Pub. Co.; 1902.

40. Still AT. Philosophy of Osteopathy. American Academy of Osteopathy; 1899.

41. Still AT. Asthma. In Osteopathy Research \& Practice. The Journal Printing Co.;1910:94-96.

42. Allen TW, Kelso AF. Osteopathic research and respiratory disease. J Am Osteopath Assoc. 1980; 79:360.

43. Howell RK, Allen TW, Kappler RE. The influence of osteopathic manipulative therapy in the management of patients with chronic obstructive lung disease. J Am Osteopath Assoc. 1975; 74:757-758.

44. Beal M, Morlock J. Somatic dysfunction associated with pulmonary disease. J Am Osteopath Assoc. 1984;84:179-183.

45. Beal MC. Viscerosomatic reflexes: a review. J Am Osteopath Assoc. 1985; 85:786-799

46. Wilson PT. The osteopathic treatment of asthma. J Am Osteopath Assoc. 1946; 45(11):491-492.

47. DiGiovanna EL, Riveria-Martinez S. Pulmonary Applications. In: An Osteopathic Approach to Diagnosis and Treatment. 3rd ed. Lippincott Williams \& Wilkins; 2005:618-623

48. Rowane MP, Evans P. Basic Musculoskeletal Manipulation Skills: The 15-Minute Office Encounter ( $2^{\text {nd }}$ edition). American Academy of Osteopathy; 2019
49. Morelli-Haskell MA, Sanchez J, Jr. Uncontrolled Asthma In Foundations of Osteopathic Medicine. $4^{\text {th }}$ ed. Lippincott Williams \& Wilkins; 2018:1161-1166.

50. D'Alonzo, GJr., Krachman SL, Foley W, Ettlinger H, Carreiro JE. Osteopathic Considerations in Pulmonology. In: Foundations of Osteopathic Medicine. 4th ed. Lippincott Williams \& Wilkins; 2018 1245-1252.

51. Creasy C, Schander A, Orlowski A, Hodge LM. Thoracic and abdominal lymphatic pump techniques inhibit the growth of $S$. pneumoniae bacteria in the lungs of rats. Lymphat Res Biol. 2013;11 (3):183-186. doi:10.1089//rb.2013.0007

52. Coffman KW. Asthma. J Am Osteopath Assoc. 1902:188-190.

53. Henley CE, Ivins D, Mills M, Wen FK, Benjamin BA. Osteopathic manipulative treatment and its relationship to autonomic nervous system activity as demonstrated by heart rate variability: a repeated measures study. Osteopath Med Prim Care. 2008:2-7. doi:10.1186/ $1750-4732-2-7$

54. Kuo A, Craig TJ. A retrospective study of risk factors for repeated admissions for asthma in a rural/suburban university hospital. J Am Osteopath Assoc. 2001;101(5):S14-7.

55. Downing $\mathrm{CH}$. The Respiratory Tract: Bronchial Asthma. In: Osteopathic Principles in Disease. American Academy of Osteopathy; 1988:467-70.

56. Nelson KE, Glonek T.Somatic Dysfunction in Osteopathic Family Medicine $\left(2^{\text {nd }}\right.$ Ed). Wolters Kluwer Health. 2015: 92,121.

57. Tazzi P.The behavioral-biopsychosocial model. In: The Five Osteopathic Models: Rationale, Application, Integration: From an evidence-based to a person-centered osteopathy. Handspring Publishing Limited; 2017:370.

58. Carreiro JE. Asthma. In: An Osteopathic Approach To Children (2nd edition). Churchill Livingstone; 2003:220-221.

59. Chikly B. Contraindications and Precautions for Lymph Drainage Therapy. In: Silent Waves: Theory and Practice of Lymph Drainage Therapy: An Osteopathic Lymphatic Technique. International Health \& Healing Inc; 2004:123.

60. Castillo JR, Peters SP, Busse WW. Asthma exacerbations: pathogenesis, prevention, and treatment. J Allergy Clin Immunol Pract. 2017;5(4):918-927. doi:10.1016/j.jaip.2017.05.001

61. Pepper, AN, Renz H, Casale TB, Garn H. Biologic therapy and novel molecular targets of severe asthma. J Allergy Clin Immunol Pract. 2017;5(4):909-916. doi:10.1016/j.jaip.2017.04.038

62. Krings JG, McGregor MC, Bacharier LB, Castro M. Biologics for severe asthma: treatment-specific effects are important in choosing a specific agent. J Allergy Clin Immunol Pract. 2019;7(5)1379-1392. doi:10.1016/j.jaip.2019.03.008

63. Moore KL, Dalley AF. Clinically Oriented Anatomy. $7^{\text {th }}$ ed. Wolters-Kluwer, Lippincott, Williams \& Wilkins:2014.

64. Lewis MJ, Short AL, Lewis KE. Autonomic nervous system control of the cardiovascular and respiratory systems in asthma. Respir Med. 2006;100(10):1688-1705. doi:10.1016/j.rmed.2006.01.019

65. Choi HG, Kim JH, Park JY, Hwang YI, Jang SH, Jung KS. Association between asthma and depression: a national cohort study. J Allergy Clin Immunol Pract. 2019;7:1239-1245. doi:10.1016/j.jaip.2018.10.046

66. Brumpton BM, Leivseth L, Romundstad PR, et al. The joint association of anxiety, depression, and obesity with incident asthma in adults: The HUNT Study. Int J Epidemiol. 2013; 42:1455-1463. doi:10.1093/ije/dyt15 
67. Shankar M, Fagnano M, Blaakman S, Rhee H, Halterman J. Depressive symptoms among urban adolescents with asthma: a focus for providers. Acad Pediatr. 2019; 19(6):608-614. doi:10.1016/j. acap.2018.12.004

68. Katon W, Lozano P, Russo J, McCauley E, Richardson L, Bush T. The prevalence of DSM-IV anxiety and depressive disorders in youth with asthma compared with controls. J Adolesc Health. 2007; 41(5):455-63. doi:10.1016/j. jadohealth.2007.05.023
69. Seffinger MA. Philosophy of Osteopathic Medicine. In: Foundations of Osteopathic Medicine, 4th ed. Wolters Kluwer; 2018:10.

70. Blumer T, Blumer J. Osteopathic approach to anxiety. OFPJ. 2017; 9(4):26-34

71. Toyama M, Hasegawa T, Sakagami T, et al. Depression's influence on the asthma control test, Japanese version. Allergol Int. 2014; 63 (4):587-594. doi:10.2332/allergolint.14-OA-07080

C 2020 American Osteopathic Association 